\title{
DEVELOPING ADDIE MODEL-BASED ESP COURSEBOOK
}

\author{
Luluk Iswati \\ Faculty of Economics and Business, Universitas Muhammadiyah Yogyakarta, Indonesia \\ E-mail: luluk007@umy.ac.id
}

APA Citation: Iswati, L. (2019). Developing ADDIE model-based ESP coursework. Indonesian EFL Journal, 5(2), 103-112. doi: 10.25134/ieflj.v5i2.1804.

Received: 22-03-2019

Accepted: 25-05-2019

Published: 01-07-2019

\begin{abstract}
Coursebook plays a substantial role in facilitating teaching and learning process, especially for EFL (English as a Foreign Language) learners of English for Specific Purposes (ESP). However, the widely available coursebooks do not always match with the designed program and the learners' as well as the institution' needs. To ensure that a coursebook can optimally support the goals of an ESP course, developing materials is suggested. This research aimed to develop an ESP coursebook using ADDIE (Analysis, Design, Development, Implementation, and Evaluation) model. A Research and Development method was employed in this research in which the data were collected through questionnaire and interview. The questionnaire was distributed to 430 Business English 1 students at Universitas Muhammadiyah Yogyakarta. Meanwhile, the interview was conducted to 4 English teachers. Here, the data were obtained during the first and the last steps of ADDIE model (analysis and evaluation). The data obtained from the analysis phase were used for need analysis, while those obtained from the evaluation phase were used to evaluate the strengths and weaknesses of the coursebook. The findings showed the coursebook's elements which cover language, content, tasks, learners, and the learning are good, but the visual elements highly need improvement.
\end{abstract}

Keywords: ADDIE; coursebook; ESP; materials development; need analysis.

\section{INTRODUCTION}

The increasing demand of teaching English for Specific Purposes (ESP) for non-English department students have exposed challenges for teachers. Generally, teachers teaching ESP in non-English departments are not specially trained nor prepared to teach in a particular ESP setting. Therefore, teachers have to equip themselves with knowledge on the subject matter (content knowledge), lexis, and register. In addition to teachers' preparedness to teach ESP classes, the teaching resources can also be a problem as the available coursebooks do not always match with learners' needs as well as the institution's learning goals. Some aspects, such as socio-cultural values, task complexity, and linguistic items, may not always be suitable to be applied in a certain learning context. Apart from that, economic reason still, to some extent, becomes an issue as not all Indonesian learners can afford published coursebooks which are usually costly. Thus, if teachers impose the use of a certain course available in the market, it might burden the students, particularly those who consider price as an issue. Richards
(2001) asserts that textbooks play a crucial role in language programs, so their quality should be ensured as they can contribute to successful language learning. To respond to the conditions mentioned earlier and Richards's (2001) statement, materials to facilitate the language learning can be developed.

Developing an ESP coursebook can offer more benefits as the teacher (as well as the material developer) can perfectly portray the actual needs of the learners and the institution. Thus, the content of the designed coursebook will be more suitable for the intended learners in terms of its sociocultural values, task complexity, and prioritised linguistic aspects. Developing materials, as Richards (2001) suggests, are advantageous as the materials will be relevant for the needs of learners and institution; it gives teachers opportunity to build expertise in materials development, it will result in a reputation of commitment to language teacher, and it offers great flexibility since the materials can be revised when necessary. In a situation where the available coursebooks do not match the 


\section{Luluk Iswati}

Developing ADDIE model-based ESP coursework

course objective, it is highly suggested that teachers adapt or make new materials, although it takes time, efforts, cost, and exeperience (Frendo, 2005).

This research was aimed at developing an ESP coursebook using ADDIE model for students studying Business English 1 at Universitas Muhammadiyah Yogyakarta, Indonesia. As there are not many research which employs ADDIE model to develop ESP courses, there are two benefits that can be taken from this research. Theoretically, this research will give insight for future ESP teachers, especially Business English teachers, and materials designer on how to develop a Business English cousebook using ADDIE model.

\section{Developing teaching materials}

McDonough and Shaw (2006) argue that developing materials is strongly suggested as the available books, whether provided by the government or recommended by the institution, do not always match with the needs of the learners. Additionally, McDonough and Shaw (2006) point out that developing materials is time investment. By investing time to develop materials, it will save teachers' time for preparation.

Further, according to Graves (2000), materials development is the process of planning in which purposes and aims of the course are embeded in units and tasks. It means that the content of the developed materials should lead to the achievement of the learning goals. Once the course objectives are set, the material developers should be able to design activities, select language functions, vocabulary focus, written or spoken texts, and exercises, which accommodate learners to achieve the desired learning goals dispersed in each given unit.

In developing materials, teachers do not always have to produce materials from a scratch. As Tomlinson (2011) states, material development is not only a process producing materials for language learning, but it can also be an integral process of adapting, designing, producing, exploiting, and researching. Furthermore, Tomlinson (2011) adds that materials development also involves the study of how to design, implement, and evaluate the materials. It is also a practical undertaking which means that the process of materials development involves not only teachers as the materials developers, but also learners. Both of them are the sources of language input as they take part in making use of sources to promote language learning.

\section{Review of ESP previous studies}

Speaking of ESP course, Dudley-Evans and St. John (1998) address three key points. First, the design of ESP should meet the specific needs of the intended learners. Second, ESP applies methodology and activities which are related to the disciplines. Third, the focus of ESP comprises four aspects, namely language, skills, discourse, and genre. Other characteristic of ESP marks a fundamental difference of ESP from EGP.

In this sense, Romanowski (2016) states that in ESP, the teacher is no longer the most knowledgeable person in the classroom in regard with the content knowledge. It is highly likely that the students, having been more familiar with the content related to their field of study, are more knowledgable than the teacher. Meanwhile, Agustina (2014) suggests that for non-English department students, the role of English is not absolute, but a means to learn a certain field of study. Therefore, there should be a balanced proportion of the teaching focus - the language aspects and how those aspects are used to communicate ideas in relation to students' field of study.

Some studies on ESP have revealed some facts that become concerns. A study by Kusni (2013) revealed some conditions concerning ESP issues in Indonesia. Here, the study showed that regarding the published ESP coursebooks which are available in the market, not many coursebooks were developed based on needs analysis, thus they may not be always suitable to be used. Kusni's (2013) finding indicated that developing ESP materials becomes necessary as it will answer the needs of the learners and the respective institution. Regarding the needs analysis, a 
study conducted by Bachir and Alazis (2016) showed the importance of needs analysis, as both teachers and learners are aware that in order to achieve the course objective, needs analysis should be done. Conducting needs analysis is not only important for the achievement of the course, but also for learners' needs.

Moreover, a study by Azaarnoosh and Ganji (2014) suggested that a coursebook should accomodate learners' individual differences and their learning style. Regarding ESP teaching materials, Poedjiastutie (2017) revealed that ESP teachers often use inappropriate materials. Instead of using materials which are specifically designed for ESP learners, teachers tend to use those intended for teaching general English. This can be a problem that can hinder the achievement of the learning objectives. Poedjiastutie's (2017) finding implies that teaching materials in ESP becomes a serious issue that needs attention.

\section{ADDIE model materials development}

According to Molenda (2015) as cited in Hess and Greer (2016), ADDIE model is an instructional design which employs processbased approach to develop instructional materials. In their study, Wang and Hsu (2016) stated that as an instructional design, ADDIE model was adopted so that learners would improve their knowledge and skills. As language teaching contains of a set of instructional materials, materials developers should determine the phases of producing or developing the materials.

Peterson (2003) proclaims that adopting ADDIE model in a course is beneficial as it is more learner-centred rather than teachercentred. From the very beginning of its stages (analysis and design), learners who will take the course are highly considered. In the development phase, it is also based on learners' needs. Besides, in its implementation and evaluation, learners are highly involved. Further, Peterson (2003) asserts that ADDIE model can be applied in various teaching contexts which employ instructional design.

\section{METHOD}

This research employed a Research and Development (R\&D) method using ADDIE model. The model consists of 5 steps, namely: 1) Analysis, 2) Design, 3) Development, 4) Implementation, and 5) Evaluation. The participants involved in this research were 430 students and 4 teachers of Management Department, Universitas Muhammadiyah Yogyakarta. The students were those taking Business English as a compulsory subject. Meanwhile, the teachers were those who have taught Business English for 1 semester. Here, the data were collected by using structured questionnaire and semistructured interviews. The questionnaire was distributed to the students, while the interview was conducted to the teachers. On the questionnaire, there are five options (strongly agree, agree, neutral, disagree, and strongly disagree) that can be chosen by the participants in responding to each statement provided.

As this research applied ADDIE model, the research consists of 5 steps, namely Analysis, Design, Development, Implementation, and Evaluation. Here, the needed data were obtained from the first phase (analysis) and the last phase (evaluation) of ADDIE model. First, in the analysis phase, the researcher conducted needs analysis in order to find out the students' and the institution's needs. The needs analysis was conducted by interviewing the head of the Management Department, Faculty of Economics and Business, Universitas Muhammadiyah Yogyakarta as well as by studying the curriculum to find out the learners' outcomes and the courses offered as the content of the coursebook would be made in line with the courses of the field of study. Second, in the design phase, the course and the materials were designed based on the data from interview and curriculum analysis. The design of the course is reflected in the syllabus which covers several aspects, such as course description, course goals, learning objectives, materials, actvities, and assessment. Third, in the development phase, 


\section{Luluk Iswati}

Developing ADDIE model-based ESP coursework

the coursebook was developed after setting the syllabus. There were three major resources used in developing coursebook, including online resources, printed coursebooks, and self-made materials. The online resources and printed coursebooks were adapted by adding, reducing, or changing. Next, in the implementation phase, the developed coursebook was implemented to 430 second semester

students. Finally, the evaluation was done by collecting information concerning the use of the developed coursebook through questionnaire and interviews. The data from the interviews were used to support the questionnaires data as well as to seek suggestions for the improvement of the developed materials. In short, the phases of conducting this research are shown in Figure 1.

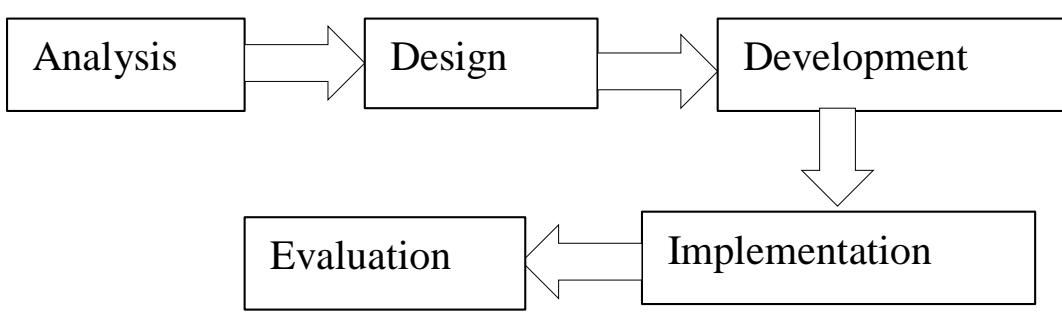

Figure 1. The phases of ADDIE model

Further, the data collected from questionnaire and interview were analyzed differently. Here, the data obtained from the questionnaire were analyzed quantitavely using 5 point- Likert scale, while the data obtained from interviewing the teachers were described qualitatively.

\section{RESULTS AND DISCUSSION}

This research reportd the development of an ESP coursebook using ADDIE model. Therefore, the findings will revolve around how materials were developed by using that model. The findings are categorized based on each step, covering analysis, design, development, implementation, and evaluation.

In the analysis phase in which needs analysis was conducted by interviewing the head of the department and by analysing the curriculum, it can be concluded that in general, the role of English for the students is to equip them with skills and knowledge on how to use language expressions and lexis for oral and written communication in business contexts. This needs analysis is important since ESP coursebooks that highly accommodate the learners' needs are difficult to find, yet ESP teachers are obliged to fulfil learners' needs (Al Fraidan, 2012). Basically, there are many ways to fulfil learners' needs, one of which is by conducting needs analysis before developing materials. By doing so, what learners actually need can be identified and pre-determined. Similarly, Widhi (2016) states needs analysis is the first step that should be done because its role is as the guidance for materials development.

The design phase involves designing the course program which consists of designing the syllabus and the coursebook. According to Graves (2000), the tangible results of materials development process are the course and the coursebook. As the course is intended for beginners, the syllabus contains topics of basic business situations in which useful language expressions and terms are introduced and practiced. The course and materials are outlined in Table 1.

\section{Table 1. The course outline}

Topic 1: Occupations \& Business
Time allocation: 2 x 100 minutes
Objective: Ss will be able to use expressions and terms of business and occupations to tell about
occupations and job responsibilities.


Language function: Describing jobs /jobs responsibility

Vocabulary focus: Kinds of jobs, job positions

Activities:

-Reading " department needed to run a business"

-Listening: Occupations \& workplace

-Speaking: roleplaying on occupations

\section{Topic 2: Telephoning}

Time allocation: 2 x 100 minutes

Objective: Ss will be able to use expressions of making \& receiving phone calls, leaving \& taking a message, and making appointment

Language function: Making and receiving phone calls, and taking and leaving messages

Vocabulary focus: Expressions for telephoning

Activities:

-Speaking : roleplaying on telephoning

-Listening: Taking telephone messages

\section{Topic 3: Business meetings}

Time allocation: 2 x 100 minutes

Objective: Ss will be able to use expressions in a business meeting: opening a meeting, summarizing, closing a meeting, giving opinion, interrupting, dealing with interrupton, agreeing/disagreeing, and asking for clarification

Language function: Giving opinions, interrupting, dealing with interruption, agreeing/disagreeing, asking for clarification

Vocabulary focus: Common terms in a business meeting

Activities:

-Speaking: roleplaying on organizing a business meeting

-Listening: Identifying meeting agendas

\section{Topic 4: Business letters}

Time allocation: 2 x 100 minutes

Objective: Ss will be able to write and to reply business letters (sales \& inquiry letters)

Language function: Writing and replying a business letter

Vocabulary focus: Common terms and expressions in business letters

Activities:

Writing: Writing \& replying a business letter

The coursebook was then developed based on the above course outline. As described in Table 1, the lessons in the course are focused on using language expressions and specific lexis to equip students to communicate in some basic business settings. The lessons are distributed in 4 (four) units, each of which consists of some sections as described below.

Table 2. The coursebook content design

\begin{tabular}{l|l}
\hline Unit 1: Occupations \& business & Unit 3: Business Meeting \\
\hline A. Did you know? & A. Did you know? \\
B. Vocabulary & B. Vocabulary \\
C. Conversation & C. Conversation \\
D. Useful Expressions & D. Useful Expressions \\
E. Listening & E. Exercise \\
F. Reading & F. Listening \\
G. Exercises & G. Roleplay \\
H. Group work & \\
\hline Unit 2: Telephoning & Unit 4: Business Letters \\
\hline A. Did you know? & A. Did you know? \\
B. Conversation 1 & B. Vocabulary \\
C. Useful Expressions & C. Reading \\
D. Listening & D. Useful Expressions \\
E. Roleplay & E. Exercise \\
F. Conversation 2 & F. Writing \\
G. Useful Expressions & G. Reading \\
H. Listening & H. Useful Expressions \\
& I. Writing (roleplaying) \\
\hline
\end{tabular}




\section{Luluk Iswati}

Developing ADDIE model-based ESP coursework

It should be noted that the distributions of the language skills in each unit is different since the focus is on what language skills can best accommodate the achievement of the learning objectives. Each unit is started with a section named "Did you know?" which aims to introduce and familiarize students to the topic. To engage students with the topic of each unit, this section portrays interesting or surprising facts related to the topic. This section also serves as an "eye opener." Since the course focuses on producing learners with sound ability of oral and written communication skills in business settings, the core of each unit lies in its useful expressions. In facts, other sections are made in order to introduce and reinforce the use of the language expressions. Here, lexis also becomes important as they are used in written and audio texts. Ahmed (2013) claims that as lexis is essential for the process of acquiring a language, the teaching of vocabulary should be contextual. Most of the texts are taken, selected, and adapted from existing coursebooks and internet resources. Designing listening tasks requires careful selection of audio resources, as things such as speech rate, intelligibility, and language complexity should match with the learners' proficiency.

After developing the designed materials into a coursebook, the product was implemented. In this implementation phase, the coursebook, named as Business English 1, was used by all students taking English 2 in the department. Here, the coursebook is the main resource of the teaching learning process so that all students were obliged to have the coursebook. Although the teachers were allowed and even encouraged to teach using other resources, the coursebook became the main tool to achieve the course objectives.

The last phase is evaluation. Richards and Renandya (2002) assert that materials evaluation is worth doing as it helps us identify the strengths and weaknesses of the developed materials. Based on that consideration, the evaluation of the developed coursebook involves the participation of the coursebook users - the students and the teachers - to gain information related to the use of the developed materials. The main data of this evaluation was taken from the questionnaires distributed to 430 participants.

As questionnaire validity is important, the researcher involved an experienced materials developer to check and assess the questionnaire before distributing to the respondents. Her judgment about the content of the questionnaire resulted in some changes of the statements in the questionnaire. The questionnaire was then distributed after the course program ended. Therefore, it is a postuse evaluation. The questionnaires were distributed in the last meeting since it intends to get evaluation which is based on students' vivid recall on their use of the developed coursebook. Students were to respond each statement in the questionnaire which was categorized into four major areas, namely language, content, tasks, learning and the learners, and visuals. The components of the coursebook evaluation were adapted from Graves (2000). The data gained from the questionnaire are presented in Table 3.

Table 3. The results of questionnaire

Language

- $79 \%$ respondents agree that Business English 1 contains enough speaking skill.

- $83 \%$ respondents strongly agree that Business English 1 contains adequate listening skill.

- $83 \%$ respondents strongly agree that Business English 1 contains adequate reading skill.

- $80 \%$ respondents strongly agree that Business English 1 contains adequate writing skill.

- $86 \%$ respondents strongly agree that Business English 1 contains adequate vocabulary.

- $87 \%$ respondents agree that Business English 1 contains useful expressions related to business settings.

Content

- $88 \%$ respondents strongly agree that the topics in Business English 1 are related to business settings.

- $99 \%$ respondents strongly agree that the situations used to deliver the topics are in line with business 
settings.

- $84 \%$ respondents strongly agree that Business English 1 contains business knowledge.

Tasks

- $85 \%$ respondents strongly agree that the tasks in Business English 1 are varied.

- $82 \%$ respondents strongly agree that the tasks are close to real-business settings.

- $82 \%$ respondents strongly agree that the tasks in Business English 1 are interesting.

- $86 \%$ respondents strongly agree that the tasks in Business English 1 are arranged from easy to difficult.

Learning and the learners

- $83 \%$ respondents strongly agree that Business English 1 has helped them develop a positive attitude towards English.

- $82 \%$ respondents strongly agree that they use Business English 1 confidently.

- $82 \%$ respondents strongly agree that Business English 1 promotes interaction among learners.

- $79 \%$ respondents agree that they apply learning strategy when using Business English 1.

Visuals

- $79 \%$ respondents agree that images/illustrations in Business English 1 are related to business.

- $79 \%$ respondents agree that the images/illustrations in Business English 1 help them comprehend the content.

- $75 \%$ respondents agree that the images/illustrations in Business English 1 are interesting.

- $77 \%$ respondents agree that the images/illustrations in Business English 1 motivate them to learn.

In general, Table 3 shows that students' evaluation on the coursebook results in positive feedback as their responses are mostly "strongly agree" and "agree." The data also indicates that the students are satisfied using the coursebook as it accommodates them to learn the language skills and aspects related to their field of study. As seen in Table 3, the evaluation elements are not solely focused on the object being assessed (the coursebook), but also involve the affective and interpersonal relation among the coursebook users. Affective factor in learning a foreign language should be taken into account as it determines how much input can be acquired by learners (Krashen, 1982; Ni, 2012). As it can be seen in Table 3, the students developed a positive attitude towards English. They also claimed that they were confident when using the developed coursebook. To a great degree, self confidence affects how learners perform the language skills (Ni, 2012).

Another evaluation was carried out by interviewing four teachers teaching Business English 1. To minimize bias which might occur since the researcher was also the materials developer, the interviews were primarily focused on seeking constructive feedbacks and suggestions so that the future coursebook can be well developed.
Regarding the linguistic aspect, especially the lexis/vocabulary, two teachers commented that although each unit of the module provides glossary which is very helpful for students, it still lacks repetition used in activities or in texts of the related unit or the units that follow. Laufer and Hulstijn (2001) propose that for successful vocabulary acquisition, learners should frequently encounter and use it in given activities. In other words, the activities or texts provided in the coursebook should contain vocabulary which is repeatedly used.

Concerning the content, there are two essential findings. First is related to the audio materials. Two teachers explained that the audio materials are too difficult for students because the speakers mostly speak with high speech rate. Consequently, many students were not successful in accomplishing the listening exercises although the teachers have replayed the audio three or more times. Hayati (2010) argues that slow rate of speech will assist learners' comprehension on the audio being played as they will have adequate time to process the information. Especially for learners of basic competence in English, careful selection of audio materials is crucial. In addition, Cunningsworth (1995) asserts that it is important to assure that the quality of the audio is good. 


\section{Luluk Iswati}

Developing ADDIE model-based ESP coursework

Telling about the topics, one teacher argued that Unit 1, which is about occupations, will be better if the examples of occupations being talked in the dialog section is about nowadays job so that it is close to the reality. In fact, many nowadays jobs are related to the use of internet or computer technology, such as graphic designers, online marketer, web designer, etc. Speaking of the business situations which are given in the coursebooks, three teachers suggested that in order to cater students with more opportunities to practice using the related vocabulary or language expressions, the coursebook should give more business situations which are reflected in the spoken texts (dialogs).

The most essential finding is the visuals of the coursebook. It is contradictory to the data gained from the students that all teachers claimed that the visuals of the coursebook need improvement. It includes the appearance, layout, and illustrations of the coursebook. Concerning the layout, one teacher suggested that the layout should be made more attractive. The developed coursebook has not made use the space efficiently so that there is some empty space. Concerning the visuals, all respondents commented that the coursebook is not appealing as the coursebook is in black and white print. Besides, it lacks illustration and images. As a result, the visual of the developed coursebook could hardly attract learners' attention.

In this sense, Tomlinson (2011) points out some important aspects in coursebook evaluation which consist of, among others, the book's ability to evoke learners' interest and motivation in using it as a tool for learning. $\mathrm{Ni}$ (2012) claims that motivation in language learning is significant as it influences learners in their process of acquiring the language. Motivation can be generated through a good coursebook which is motivating. One of the ways to present motivating aspect in the coursebook is through visuals. Visual elements should be considered especially in EFL contexts because students have little exposure of
English (Hill, 2003; Porcaro, 2001; Wright \& Haleem, 1991). The importance of pictures are also confirmed by Romney and Bell (2012) who point out that the role of pictures are either decorative or instructional. Decorative refers to aesthetic value that may generate students' interest in using the coursebook, while instructional refers to the function of a coursebook which contain sets of instruction to do activities or tasks.

\section{CONCLUSION}

The development of an ESP coursebook using ADDIE model has resulted in a product named Business English 1. The development of the current coursebook underwent five steps, namely analysis, design, development, implementation, and evaluation. In the process of adopting ADDIE model, the researcher gained data from the stakeholder (the department) and the coursebook users which was carried out in the beginnning phase (analysis) and the last phase (evaluation). The design and development of the coursebook are highly influenced by the result of needs analysis, from which what are to be taught through the coursebook are predetermined.

Regarding the evaluation, there are interesting findings. Despite students' positive response to the statements in the questionnaire which implies a certain extent of effectiveness of the coursebook, it is crucial to pay attention to the findings in the interview. The teachers claimed that the developed coursebook lack attention concerning its visual elements. To some degree, visual can generate students' interest in using the coursebook as a means to learn the language. Thus, it hints an improvement of the developed coursebook which will be focused on enhancing its visual elements.

As there are not many research which study the use of ADDIE model for ESP materials development, it is suggested that researchers interested to conduct similar study in ESP area explore the application of ADDIE model for ESP materials development in depth. It is also strongly suggested that the analysis phase involve not 
only the stakeholders, but also the main users of the future coursebook (students). In addition, to gain more convincing and larger data, interview can also be conducted to students, not only teachers.

\section{ACKNOWLEDGEMENT}

The writer would like to thank LP3M of Universitas Muhammadiyah Yogyakarta for funding this research.

\section{REFERENCES}

Ahmed, A. O. A. (2013). Lexis development: The importance of contextual clues. European Scientific Journal, 9(3).

Agustina, T. (2014). English for specific purposes (ESP): An approach of English teaching for nonEnglish department students. Beta Jurnal Tadris Matematika, 7(1), 37-63.

Al Fraidan, A. (2012). Evaluation of two ESP textbooks. English Language Teaching, 6, 43-47.

Bachir, K., \& Alazis, M. G. (2016). Designing ESP course: Setting objectives for business learners. (Unpublished Dissertation). Department of Letters and English Language, Ourgla University. Retrieved on August 15, 2018 from https://bu.univ-ouargla.dz/master/.../KHERFIGUEZIZ.pdf.

Cunningsworth, A. (1995). Choosing your coursebook. Oxford: MacMillan Heinemann.

Dudley-Evans, T., \& St John, M. J. (1998). Developments in English for specific purposes: A multidisciplinary approach. Cambridge: Cambridge University Press.

Frendo, E. (2005). How to teach business English. Pearson: Longman.

Graves, K. (2000). Designing language courses: A guide for teachers. Boston: Heinle \& Heinle Publishers.

Hayati, A. (2010). The effect of speech rate on listening comprehension of EFL learners. Creative Education, 2, 107-114.

Hess, A. K. N., \& Greer, K. (2016). Designing for engagement: Using the ADDIE model to integrate high-impact practices into an online information literacy course. Communications in Information Literacy, 10(2).

Hill, D.A. (2003). The visual elements in EFL coursebooks. In B. Tomlinson (Ed.), Developing
https://journal.uniku.ac.id/index.php/IEFLJ/index

materials for language teaching (pp. 174-182). London: Continuum Press.

Krashen, S. (1982). Principles and practice in second language acquisition. Oxford: Pergamon Press.

Laufer, B., \& Hulstijn, J. (2001). Incidental vocabulary acquisition in a second language: The construct of task-induced involvement. Applied Linguistics, 22(1), 1- 26.

McDonough, J. \& Shaw, C. (2006). Materials and methods in ELT: A teacher's guide. Oxford: Blackwell Publishing

Ni, H. (2012). The effects of affective factors in SLA and pedagogical implications. Theory and Practice in Language Studies, 2(7), 1508-1513.

Peterson, C. (2003). Bringing ADDIE to life: Instructional design at its best. Journal of Educational Multimedia and Hypermedia, 12(3), 227-241.

Poedjiastutie, D. (2017). The pedagogical challenges of English for specific purposes (ESP) teaching at the University of Muhammadiyah Malang, Indonesia. Academic Journals, 12(6), 338-349.

Porcaro, J. W. (2001). Newspaper cartoons. Modern English Teacher, 10(2), 29-33.

Richards, J. C. (2001). Communicative language teaching today. New York: Cambridge University Press.

Richards, J., \& Renandya, W. (eds.) (2002). Methodology in language teaching: An anthology of current practice. Cambridge: Cambridge University Press.

Romney, C., \& Bell, L .(2012). The role of graphics in business English textbooks. In K. BradfordWatts, R. Chartrand, \& E. Skier (Eds.), The 2011 pan-SIG conference proceedings (pp. 210-219). Matsumoto: JALT.

Tomlinson, B. (2011). Materials development in language teaching (2nd ed.). Cambridge: Cambridge University Press.

Wang, S., \& Hsu, Hu-Yin. (2009). Using the ADDIE model to design second life activities for online learners. Techtrend, 53(6), 76 - 81.

Widhi, V. S. N. (2016). Developing Kemp modelbased supplementary ESP materials in e-book format for hotel accommodation program students of vocational high school. Unpublished master's thesis. Department of Language and Arts Education. Universitas Lampung.

Wright, A., \& Haleem, S. (1991). Visuals for the language classroom. Harlow: Longman. 


\section{Luluk Iswati}

Developing ADDIE model-based ESP coursework 